\title{
Should Public Blame replace the Criminal Trial? A comment on R A Duff, The Realm of Criminal Law*
}

\author{
GUSTAVO A. BEADE \\ University of Palermo
}

\begin{abstract}
What should we do in cases in which public blame takes an important role? Should we rely on it and forget about Institutional alternatives? Here I present one of Duff's new developments from The Realm of Criminal Law that will certainly generate new debates: the right to be prosecuted. I begin with an example followed by an argument that I believe will meet with Duff's approval. My goal in the paper will be to expand the right to be prosecuted, as presented in The Realm of Criminal Law and argue that the proper solution will be to defend the exercise of the right to be prosecuted and respond to the accusations.
\end{abstract}

Keywords: public blame, criminal trial, communicative punishment, right to be prosecuted.

\section{INTRODUCTION}

During the last ten years I have been inspired by Antony Duff's work and developed many of my own central ideas in reference to this corpus. However there has always been something that concerned me about Duff's ideas on blame and the communicative function of punishment. ${ }^{1}$

I have doubts about Duff's response to particular cases, e.g.: should we have punished $\mathrm{X}$ for doing $\mathrm{Y}$ ? or do we have moral standing to blame $\mathrm{X}$ for

* For helpful comments and criticisms I am grateful to Fernando Bracaccini, Roberto Gargarella, Tatjana Hörnle, Santiago Mollis, Ezequiel Monti, Gideon Yaffe, two anonymous reviewers and of course, Antony Duff. I would also like to thank José Luis Marti for organizing the symposium on this book in Barcelona in February 2019. Finally I would like to thank the University of Palermo for the financial support during the writing of the paper.

1 For instance, there are identifiable differences about blame in particular between what he said in Duff (1986) and in Duff (2010). 
doing Y? At the same time, Duff's framework has often been characterized in different ways: many legal theorists read him as being close to abolitionism, although Duff is not an abolitionist. Others criticize him for being neither a pure liberal nor a pure republican. Over the past ten years Duff many times criticized abolitionism and developed a particular liberal republican approach. Nevertheless, confusion still surrounds his work.

Here I present one of Duff's new developments from The Realm of Criminal Law that will certainly generate new debates: the right to be prosecuted. I begin with an example followed by an argument that I believe will meet with Duff's approval. Ultimately, my goal will be to expand the right to be prosecuted, as presented in The Realm of Criminal Law.

\section{INCITEMENT TO RAPE}

I begin with a particular example which I will call Mr. Lamb's case: Mr. Lamb is a musician and well recognized public figure in his country. During a promotional event for his forthcoming record, he surprisingly makes claims such as, "It is a legal atrocity that if a sixteen years girl wants to have sex with you, you can't because it is forbidden," or even more notoriously, "Some women need to be raped to have sex because they are hysterical and feel guilty for not being able to have sex freely," and something like, "What are these so-called 'Rights of Women'? I do not believe in the laws of men, but only in those of nature." Obviously, such statements will generate a public outcry.

Suppose that many citizens begin to protest against him, discussions erupt in social networks, and the media rejects his claims. Public blame and censure against him is unanimous and everyone agrees that Mr. Lamb is wrong. Some of his fans refuse to continue to listen to his music and not a single other musician will defend him in public. After the conference, radio and TV stations decide not to play his music and concert promoters throughout the country cancel his shows. A few days later, Mr. Lamb presents a written statement apologizing for his conduct and explains that he was misunderstood. However, after the negative response from the public he decides to cancel his forthcoming tour to promote the new album and to retire - temporarily - from the music business.

I assume that many legal theorists and philosophers would say that we have censured and blamed Mr. Lamb enough. ${ }^{2}$ Many would probably say that we should be satisfied because we live in a polity that rejects these kinds of conduct and forget about the issue, suspending recourse to any

2 See for instance Husak (2010: 433) 
Should Public Blame replace the Criminal Trial?

A comment on R A Duff, The Realm of Criminal Law

sort of legal procedure. I think that blame plays a central role in our relations with other members of our communities and consider that sometimes public blame or critical attitudes e.g., public humiliation, 'lynching' in the mass media, is probably the only kind of social response in a political community. ${ }^{3}$ Blame is an expression of the community's disapproval and clearly distinguishes who is the subject of reactive attitudes and who is not: therefore, blame stigmatizes but also acquits. Furthermore, constitutes the foundation on which a certain type of retributive-communicative punishment is based. ${ }^{4}$ However, I am unconvinced about relying heavily on public blame. I believe that in this particular case we need to do something more than expressing anger and disapproval. ${ }^{5}$ If Mr. Lamb committed an offense (probably an incitement offense), we should prosecute him and put him on trial.

In what follows I will defend the idea that we should prosecute him and call him to account. I tentatively expand Duff's idea of the conditional right to be prosecuted and argue against the idea that public blame generates enough censure for Mr. Lamb.

\section{CATEGORICAL AND CONDITIONAL RIGHT TO BE PROSECUTED}

According to Duff, to call someone to account for an alleged wrong, however condemnatory that calling to account might be, involves showing that person a certain kind of respect, even concern, as a fellow citizen who, along with everyone else, is bound and protected by the values to which that calling to account appeals (Duff, 2018:210). To say that we owe it to the wrongdoer to call him to account is to say that he has a right to be thus called to account and, therefore, if the calling to account takes the form of a criminal prosecution, a right to be prosecuted. However, Duff distinguishes between a conditional right and a categorical right to be prosecuted.

The conditional right to be prosecuted is the right that if we are going to respond to the wrong in a way that enacts or displays our condemnation of it, and that bears adversely on the perpetrator, we should prosecute him rather than subject him to other kinds of an adverse response (Duff, 2018: 210). When he refers to these other responses, Duff is thinking about

3 About the (possible) relationship between public blame and criminal law see Hörnle (2018).

4 I developed this idea in Beade (2019).

5 I would like to thank an anonymous reviewer for encourage me to develop this point. 
immediate ostracism or exclusion, or about punishment without a trial, which he describes as lynching. A categorical right to be prosecuted would be a right to be prosecuted even if the alternative was simply to have one's wrong ignored. On Duff's view the right to be prosecuted can be categorical rather than a merely conditional right. If to prosecute someone is to address her as a responsible member of the political community, as a participant in this form of civic life, it is an aspect of what we owe to each other as fellow citizens: the 'equal concern and respect' that we owe each other, the recognition of each other as fellow citizens, is displayed in, inter alia, our responses to the wrongs that we commit. To fail to respond to another's wrong, when that other is a fellow citizen and the wrong a (non-trivial) civic wrong, is to imply that neither she nor her wrong is worthy of our attention or notice; but that is not how we should address our fellow citizens (Duff 2018: 210). However, a categorical right to be prosecuted or punished is not an absolute right: there might be good reasons not to prosecute, or punish, culpable wrongdoers (for instance, having to do with 'the public interest;' in which case, non-prosecution or non punishment does not violate their rights (Duff, 2018: $211 \mathrm{n}$ 95)).

According to Duff, what we owe to victims and perpetrators is not (simply) to condemn the wrong or the wrongdoer. Condemnation does indeed express a concern for the victim, and for the values which that wrong violated and it at least implies a recognition of the wrongdoer as a responsible agent: but it does not by itself address him as a responsible fellow member of the normative community, because it does not require or invite him to respond to the charge of wrongdoing - to deny the charge, to defend himself, or to accept his guilt. A polity that is quick to exclude wrongdoers might not invest much in a process that calls wrongdoers to answer for their deeds - beyond what was needed to make reasonably sure that they were guilty. But a polity that takes an inclusionary attitude to its members and that still treats them as citizens even when they commit serious wrongs, will be committed to calling them to account for their civic wrongdoing (Duff 2018: 211).

Let me return to Mr. Lamb's case: he has been censored and his behavior was widely criticized in the media. His statements were rejected by a large part of the polity who believe that there are matters about which we agree: that we - as members of the polity - do not trivialize sexual assaults and the suffering of the victims and that we respect the laws that govern us and punish those crimes. We assume that there are things that we are not willing to accept passively. In addition, the actions taken by some private companies to cancel his shows and stop playing his music are a sign that 
Should Public Blame replace the Criminal Trial?

A comment on R A Duff, The Realm of Criminal Law

these are public matters. In short, it seems that Mr. Lamb received what he deserves and it seems that to call him to account, to prosecute, and to punish him will not add anything but suffering.

I criticize many of the decisions that were taken as a result of Mr. Lamb's claims. I do not think that censoring his music on the media, cancelling his concerts, nor hurting him financially are fair decisions. In fact, they are out of proportion and undeserved because they affect people other than Mr. Lamb. These actions affect his musicians and his staff as well. They lost their jobs and their future seems to be compromised by these decisions. It does not matter how much anger we feel, nor how much we repudiate Mr. Lamb on social networks. The central point is that beyond individual and unconnected responses such as public blame we need a response from someone who represents us as an authorized member of the polity. Someone that can speak in the name of the polity. Moreover, we owe Mr. Lamb an adequate treatment for his conduct. This is where the right to be prosecuted plays a significant role. In Mr. Lambs' case, the right to be prosecuted will be conditional and categorical. Public blame initially results in ostracism and exclusion for Mr. Lamb, but then this kind of blame will be probably ignored by public officials.

The categorical and conditional right to be prosecuted seem to be important categories when we think about prosecution and trial. However, at first sight these look like underdeveloped categories. Taking into account Mr. Lamb's case there are two important questions that need to be answered; For example, why to prosecute or not Mr. Lamb will be the first decision that a polity needs to take when facing similar situations? Or why should Mr. Lamb agree to be prosecuted? In what follows, I will try to answer these two questions.

\section{WHY PUBLIC BLAME IS NOT ENOUGH}

Although, members of the polity individually expressed themselves and private corporations took decisions that censured Mr. Lamb's claims, the polity as a whole has not said anything about Mr. Lamb. However, how can the polity express itself? Evidently, there are several ways whereby a polity can express itself. I cannot present them all here, but prosecutors should represent the polity as a whole in cases like this. If a prosecutor reports someone or starts a judicial inquiry, she is speaking in the name of the polity. The prosecutor as a member and a representative of the polity will may be able to discuss and refute each of Mr. Lamb's claims and remind Mr. Lamb that the "laws of men" are his laws, and that in this polity we do 
not tolerate such assertions. Furthermore, a prosecutor will point out that nature (or the laws of the nature) does not force us to treat women as if they were objects.

However, someone might ask what would be the point of calling him to account and threatening him with a criminal trial (and claim that as his right!) when we have already censured and blamed him. We might be accused of prosecuting Mr. Lamb as a consequence of social pressure or because we are advocates of penal populism. Furthermore, someone could argue that in virtue of the rage that the case has provoked it seems to be undeniable that Mr. Lamb's trial will be seriously contaminated and this could constitute another type of retaliation. Nevertheless, my argument is that, apart from public blame and private responses against Mr. Lamb, if we are advocates of a communicative theory of punishment the polity as a whole must do something. The aim of calling him to account and putting him on trial is to give him an opportunity to explain what he did (and why he did it), realize that he made a mistake and, if he wishes, to repent for what he did and (if possible) to repair the harm he caused. ${ }^{6}$ The fact that Mr. Lamb's statements where rejected and discussed in the polity is not a reason to suspend or left aside the reasons that we have to prosecute him. If Mr. Lamb suffered disproportionate public blame we would not have strong reasons to prevent $\mathrm{Mr}$. Lamb from being prosecuted but to guarantee a proportionate trial. ${ }^{7}$

The offender's repentance and apology after thinking about the censure of the polity in which he lives allows him to recognize that what he did was wrong. Note that the idea of imposing suffering in order to facilitate an apology has met with some criticism. ${ }^{8}$ Some people might have doubts about the general idea: why would an offender apologize after committing a crime? Why should Mr. Lamb repent for what he did? My answer would be the following: Mr. Lamb is part of this polity and he probably wants to continue to belong to it and actively participate in it. Repentance allows for this possibility. Under these circumstances the polity is obliged to react positively to the apologies or the repentance of an offender. ${ }^{9}$ Let me elaborate further on this idea.

6 According to Michelle Madden Dempsey this is an act that kicks off a moral dialogue. See Dempsey (2015).

7 I thank an annonymous reviewer for prompting me to reflect on this issue.

8 See for instance Tadros (2011: 101).

9 To call someone to account also generates certain obligations for the polity. One of them is to be willing to listen to the offender's reasons and to re-integrate him quickly after being punished. Unfortunately I cannot develop this point further here. However I think that is related to the problem of the so-called collateral restrictions. See Hoskins (2016). 
In one, perhaps, overrated idea of the criminal trial, Mr. Lamb can give reasons that explain what he did. Moreover, we - the polity - need to listen to him. It is important, when guaranteeing his right to be prosecuted, to understand why he is prosecuted and why what he said constitutes an offense. In J.M. Coetzee's Disgrace a university professor, David Lurie, is accused of having a relationship with a student named Melanie Isaacs and must appear before a special university committee. Lurie is informed of the charges against him, which are based on a statement by Melanie Isaacs and a report that although Melanie did not attend his classes, nor take exams, Lurie gave her a passing grade for the course. Wishing to finish the investigation quickly, Lurie pleads guilty. However, when the committee asks Lurie which of Isaacs' claims he accepts, he responds that he accepts all of Isaacs' statement without giving any reasons. He says that she has no motives to lie. The committee insists that Lurie read Isaacs' statement. He refuses to do so. This situation creates a problem for the committee members who have reservations about ending the matter without delving deeper into what happened. They tell Lurie that the community has the right to know which of her claims he accepts and that it is also necessary for him to know why he is being censured. Lurie stands by his refusal to read her statement. Finally, he is suspended and expelled from the University.

In Disgrace, the boundaries of the polity collide with the right of someone to refuse to explain what happened. The polity cannot force citizens to accept or discuss the details of an accusation. A defendant can make use of a specific right to explain what has happened but we cannot put him under a legal obligation to do it. We cannot claim that a polity may demand an explanation, nor therefore maintain that the wrongdoer is under an obligation to explain himself.

Nevertheless, repentance is an act which is important in re-establishing the relationship between the offender and the community. If I am part of a certain community and I make a mistake, I would not like to be excluded from the community. I am part of the community, I belong to it, and I have an interest in continuing to be a member. It is my interest in being part of a community (or a polity) which gives me reasons to recognize my errors and to repent for what I have done. For these reasons I will be able to accept the right to be prosecuted. It is clear that the community also has obligations that derive from the wrongdoer's repentance. Among these, I think, are the obligations to accept repentance and to welcome the person who intends to return to be part of the community. Needless to say that respect for the rule of law will be part of the right to be prosecuted and of the trial. Another prior obligation therefore will be to secure access to the right to be 
prosecuted in order to avoid unwanted acts of public lynching. ${ }^{10}$

Duff claims that the trial is a process through which citizens are made to answer to charges by their fellows citizens of civic wrongdoing and to answer for that wrongdoing if the charges are proven: it thus provides an appropriate response to what the polity defines as crimes. The trial constitutes the calling to account that civic wrongdoing requires - a calling that takes the wrongdoing seriously and addresses its agent as a responsible citizen. That trial focuses on that wrongdoing as a public rather than a private matter: the polity calls the alleged perpetrator to account for a wrong that concerns all citizens. However it respects the bounds of private life: what is at issue is whether the defendant is guilty of the particular wrong specified in the indictment; only matters bearing directly on that issue are to figure in the trial (Duff 2018: 214).

Advocates of restorative justice might suggest that there will be better opportunities for a communicative process in a different kind of informal process. However, I am unpersuaded by their arguments. Let me say something about this alternative.

\section{WHY NOT THE RESTORATIVE JUSTICE ALTERNATIVE?}

Calling to account, as a way of treating each other as responsible agents, might not seem to require a formal criminal process. Duff suggests that the advocates of restorative justice often also make responsibility salient in their accounts of how we should collectively respond to (what we see as) crimes, but they advocate informal processes of mediation rather than a formal process like the criminal trial. ${ }^{11}$ What is important, they argue, is to developless formal structures and procedures through which responsibility can be discussed, negotiated, accepted, and discharged - through which people can take responsibility for their actions and agree on how to discharge that responsibility through reparative actions. They differ, however, over just what those structures and procedures should be, and sometimes they fail to appreciate the significance of the distinctive kind of calling to account that the criminal law can provide. However, according to Duff, a process that is to do justice to victims and to what they have

10 To blame someone means pointing out that that agent did something wrong; blame is conceptually linked to wrongdoing. If blame implies the idea that we are treating the offender as a moral agent, as a member of our moral community we can expect that the she could offer a justification or and excuse that explains what she did. In this sense blame could be perceive as a form of dialogue. As I understand it public lynching is far from being considered as a dialogue but to an extreme way of accusation.

11 See e.g., Walgrave (2008) and O’Mahony and Doak (2017). 
Should Public Blame replace the Criminal Trial?

A comment on R A Duff, The Realm of Criminal Law

suffered must not merely aim at calling the perpetrator of harm to account or at bringing him to recognize his responsibility for that harm, but must also call a wrongdoer to account for the wrong that he has done.

Duff argues that the advocates of restorative justice often prefer an informal negotiation between the parties (who are most directly involved in the case) rather than a formal determination by a court. What matters, they argue, is that people should discuss their concerns, explain their actions and reactions, freely and openly. They should be able to come to accept their own responsibilities and to recognize that the responsibility for a harm might not be properly allocated to just one person. We might do better to try to resolve our problems through such informal processes rather than by appealing to the formal (and coercive) apparatus of the criminal law. But, according to Duff, such informal processes will not always be adequate. Duff proposes that some kinds of wrong should be treated as public matters which concern us all as citizens. If these wrongs violate our collective values, that gives us reason to look for a formal, public, collective response (Duff 2018: 212).

Duff claims that we should treat as typically public wrongs those acts that require categorical recognition and condemnation rather than the kinds of nuanced negotiation that a 'conflict' oriented process is likely to involve. It is difficult to think about institutional alternatives in which Mr. Lamb responds without being forced to do so and having the chance of offering a justification, an explanation, expressing regret, offering compensation, or taking part in a kind of dialogue. Mr. Lamb's offense is one that has no particular victim but the polity. It directly violates our values and, as Duff advocates, it is a kind of wrong that should be treated as a public matter. When we commit wrongs that count as 'public,' we must be willing to answer for them publically (Duff 2018: 213). If we propose an alternative to this we will be favoring the privatization of the conflict, one in which the polity will not take part. Moreover, if our starting point was public blame, we will need to think of a public process like a trial. In short, if we are to call wrongdoers to account, we must establish that they are wrongdoers first. And if we are to do that in a way that treats them as responsible citizens, we should do it through a process that invites them to answer the accusation of wrongdoing and which protects them against unwarranted judgments of guilt (Duff 2018: 214).

\section{PROSECUTING INCITEMENT IN A LIBERAL REPUBLIC?}

There is one issue, which is not central to the argument, but which I need to tackle. Mr. Lamb will be accused of committing an offence of incitement 
(or encouragement), i.e. to persuade or encourage others to commit a crime. ${ }^{12}$ My argument is that we have a particular offense of incitement and we need to decide if we are going to prosecute Mr. Lamb or not. However, in normative terms, the question is: should we prosecute citizens for incitement offenses in a liberal republic?

Probably influenced by liberalism I used to have reservations about this kind of inchoate offenses. I used to think that to criminalize this kind of conduct overestimates the influence certain people have over others and underestimates the critical faculties of the recipients of those messages. If we accept that we live in a democratic polity composed of autonomous citizens, i.e., agents that can make their own decisions, the criminalization of this type of behavior appears to be insulting. Autonomous citizens are able to make their own decisions and have the capability to avoid committing wrongs. ${ }^{13}$ Many of the prosecutions for incitement are related to the use of drugs or the promotion of certain substances. However, I am skeptical about the influence that defenders of certain drugs could have on autonomous citizens. Such defenses may possibly influence people under a certain age but they are unlikely to influence adults. We have, as adult citizens, different visions and moral judgments about the good and the bad. Our own decisions make us responsible, rather than any "suggestions" by others. Thus, it is difficult to understand why we should accept incitement offenses in a liberal republic. However, let me try to present an answer based on Duff's account.

According to Duff, the criminal law's primary purpose is the provision of an appropriate response to those kinds of moral wrong that constitutes public wrongs. Taking this into account, Duff argues that one function of the substantive criminal law is simple declarative: the polity has reason to declare (in some suitable formal way) the norms that its citizen have determined should guide their civic conduct - its public norms. Duff's modest claim is that an institution can have good reasons to make a formal declaration of the norms that are to guide its members' conduct beyond the desire to ensure compliance with those norms by threatening sanctions against those who violate them. These are norms whose breach will render perpetrators liable to a formal public response (Duff 2018: 206-207). However, even without the prospect of punishment, such formal declarations of what constitutes public wrongs can have some preventive effects: they can remind us of how we should or should not conduct ourselves and they can warn us that if we fall short in our conduct we will face the prospect of being prosecuted. Furthermore, even without the

12 More details in Ashworth \& Horder (2013: $476 \mathrm{ff}$ ).

13 See Husak (1992). 
prospect of punishment following a conviction, the prospect of prosecution can have a dissuasive effect, since prosecution itself is a burdensome business and conviction is, for most people, unwelcome and unpleasant.

There are differences between drug cases and Mr. Lamb's case. In particular, Mr. Lamb's case looks like an "Incitement to Hatred" offense. ${ }^{14}$ Duff argues that to hate a fellow citizen is thus already a lack of civic virtue, i.e. a lack of concern and respect for others. However, if I act simply as an individual who hates another individual, nothing of civic importance might hang on my action. If my conduct has a collective aspect and is directed against members of an already vulnerable group, its character changes: if my hatred is directed against a group, treating them as contemptible or hateful, as disqualifying members from proper citizenship, then such conduct becomes genuinely threatening (Duff 2018: 200-201). In this case, Mr. Lamb, fails to recognize others (women in particular) as equals and as fellow citizens and this makes a big difference in comparison to drug cases.

\section{FINAL REMARKS}

Remain calm, my abolitionist friends: there is no risk of imprisonment for Mr. Lamb. He will exercise his right to be prosecuted and will be able respond to the accusations. To call him to account will allow him to limit disproportionate public blame and give him the chance to defend himself against the polity's representative: the prosecutor. Our common law, addressing us in our collective voice, can do much more for our civic ideals and this is part of Duff's proposal in The Realm of Criminal Law.

\section{BIBLIOGRAPHY}

Ashworth, A. \& Horder, J., 2013: Principles of Criminal Law, Oxford: Oxford University Press

Beade, G.A. 2019: "Who Can Blame Whom? Moral Standing to Blame and Punish Deprived Citizens,” Criminal Law and Philosophy 13:271

Dempsey, M.M. 2015: "Prosecuting Violence Against Women: Toward a "MeritsBased” Approach to Evidential Sufficiency," Revista Jurídica de la Universidad de Palermo 14:241

Duff, R.A., 1986, Trials and Punishment, Cambridge: Cambridge University Press

-2010, "Blame, Moral Standing and the Legitimacy of the Criminal Trial," 23(2) Ratio, 123-140

14 See for instance the German Criminal Code (StGB $§ 130$ (1)) which defines "Incitement to Hatred" as 'assault the human dignity of others by insulting, maliciously maligning or defaming segments of the population'. See also Hörnle (2012). 
Duff, R.A., 2018: The Realm of Criminal Law, Oxford: Oxford University Press

Husak, D. 1992: Drugs and Rights, Cambridge: Cambridge University Press

- "Already Punished Enough" in The Philosophy of Criminal Law, Selected Essays Oxford: Oxford University Press

Hörnle, T. 2012: "Criminalizing Behaviour to Protect Human Dignity," Criminal Law and Philosophy 6: 307

-2018: “\#MeToo - Implications for Criminal Law?" Bergen Journal of Criminal Law and Criminal Justice, Volume 6, Issue 2, p. 115-135

Hoskins, Z. 2016: "Collateral Restrictions" in Flanders Ch. and Hoskins Z., The New Philosophy of Criminal Law, London: Rowman \& Littlefield

O’Mahony, D. and Doak: J. 2017, Reimagining Restorative Justice, Oxford: Hart Publishing

Tadros, V. 2011: The Ends of Harm: The Moral Foundations of Criminal Law, Oxford: Oxford University Press

Walgrave, L., 2008: Restorative Justice, Self-Interest and Responsible Citizenship, Cullompton: Willan Publishing 